\title{
熱を受けるテンドンのすべりを考慮した張力再配分評価式
}

\section{THEORETICAL FORMULATION ON REDISTRIBUTION OF TENSILE FORCE CONSIDERING THERMAL EXPANSION IN HEATED TENDONS}

山本 幹夫*

Mikio YAMAMOTO

\begin{abstract}
In Japan, to raise the reliability of the evaluation method on remaining tensile force in tendons of pre-stressed concrete containment vessels (PCCV) under long-term behavior, an evaluation method considering the redistribution effects by tensile force is proposed.

Results from the proposed theoretical formula of friction considering thermal expansion and those of the past thermal experiment were compared. The proposed theoretical formula explains the experiment results on both the tensile strain distribution in the tendon, and temperature - strain relations.
\end{abstract}

\author{
Keywords : $P C C V$, Tensile force redistribution, Heated tendon, Friction theory \\ プレストレストコンクリート製原子炬格納容器, 張力再配分, \\ 熱を受けるテンドン, 摩擦理論
}

\section{1. 序}

近年、日本の原子力発電所においては、コンクリート製原子炬格 納容器が採用される傾向にある。コンクリート製原子炉格納容器の 内、プレストレストコンクリート製原子炉格納容器（PCCV）では、 予め構造体に圧縮応力を導入するために、コンクリートと直接、付 着力の伝達を行わないアンボンドタイプの鋼製緊張材（テンドン） が壁体内の鉛直方向及び円周方向に配置されている。円周方向のテ ンドンは 1 本のテンドンで $360^{\circ}$ の全周に亘って網羅され、その両 端部は 2 個所のバットレスで交互となるように鉛直方向に一定間隔 で配置されることが多い。図 1 に円周方向テンドンの配置例 "をを示 す。

テンドンは約 40 年閒に亘って張力の経年変化を検查することが 求められ、端部でテンドンの残存張力を測定するための試験（リフ トオフ試験）が定期的に行われている。図 2 に円周方向テンドン 1 本の張力分布模式図を示す。尚、図中の張力は、端部ではりフトオフ 荷重，中間部では計算又は推定により求まる分布である。これまで のリフトオフ試験結果 ${ }^{2), 3)}$ は概㸚良好であるが、一部のテンドンで は、テンドンの両端で張力変動量 $\left(\Delta T^{\prime}, \Delta T^{\prime \prime}\right)$ が等しくないも のもあり、変動量に倸わる要因として考えられている弾性変形ロス 及び経年変化ロス（レラクゼーション，クリープ，乾燥収縮）だけ
では説明できない性状があることが認められる。

PCCV の PS 緊張工事に於ては定着後に 2 次防錆材として約 $80^{\circ} \mathrm{C} に$ 温められたグリースがテンドンシース内に注入され、テンドンが温 められた後、自然冷却される。又、建設完了後に於ては、コンクリ 一ト構造としての健全性評価のための構造性能確認試験が加圧試験 により実施される。これらはいずれもテンドンに比較的微少なひず み変動を与え、テンドンがすべることにより張力再配分が生し、そ れが両端での張力変動量に影響を与えている要因であるものと筆者 は考えている。

このようなテンドン張力再配分の影響量を明らかにするために、 再配分を生じさせる手段の一つとして、コンクリートの中実円筒の 側面にテンドンを巻き付けてテンドンに熱を与える実験 ${ }^{4}$ が初めて 行われた。その結果、テンドンを緊張、定着した後、加熱すると、 高張力側の張力堿少が大きく、低張力側の張力減少が小さくなるの に対し、除熱後では逆に、高張力側の増大が小さく、低張力側の張 力増大が大きくなり、既往の文献 ${ }^{5), 6)}$ の繄張、定着時の張力分布性 状とは異なる性状となることを確認した。

本論文では、張力再配分の影響を実機 PCCV について評価するた めに、テンドンのすべりを考慮した摩擦理論による張力変動評価式 を提案し、前述の実験結果 ${ }^{4)}$ と比較する事により理論式の適応性を 


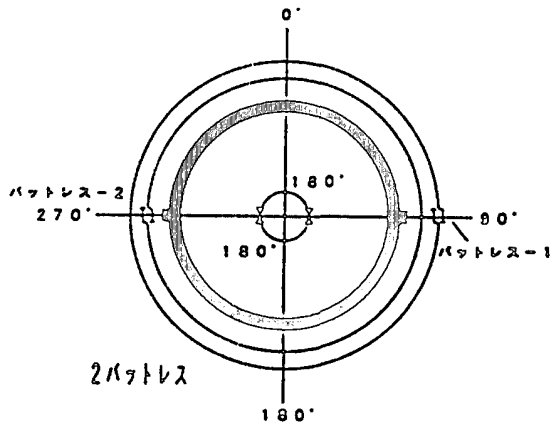

図 1 PCCV 円周方向テンドン配㯰図 ${ }^{1)}$

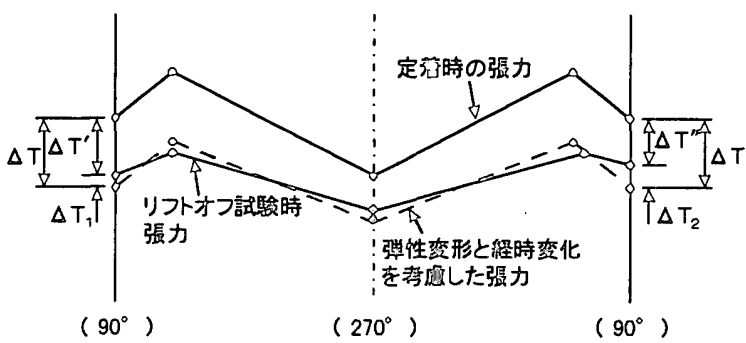

$\Delta T \quad:$ 弹社変形と縚時変化による張力变功工

$\Delta T^{\prime}, \Delta T^{\prime \prime}:$ リフトオフ試踰時の镸力変功让

$\Delta T_{1} ， \Delta T_{2}:$ 張力再配分による張力变功区

図 2 円周方向テンドンの張力分布模式図（両引き緊張）

確認するものである。

\section{2. 既往の确究}

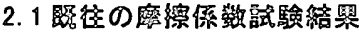

竹本 ${ }^{8)}$, 牧野 ${ }^{9)}$ は、 $1,000 \mathrm{t}$ 級テンドンの摩擦係数試験により、 テンドンをシリンダーに巻き付け、一端を固定し、他端を緊張、除 荷した時の緊張端張力 $\mathrm{P}_{0}$ と定着端張力 $\mathrm{P}_{1}$ との関倸が、図 3 のよう になることを示している。

摩擦係数を $\mu(1 / \mathrm{rad})$ ，緊張端と定着端との開角を $\alpha_{\mathrm{B}}$ とすると 緊張時においては、 $\mathrm{P}_{0}$ と $\mathrm{P}_{1}$ とは、 $P_{1}=P_{0} \cdot e^{-\mu \alpha_{B}}$ の関係を保持する が、除荷時（定着端を保持した状態で、繄張端側から除荷）におい ては、 $\mathrm{P}_{0}$ を減少させても $\mathrm{P}_{1}$ はしばらくは変動せず、 $\mathrm{P}_{0}$ が所定の 荷重になって初めて、 $\mathrm{P}_{1}$ が減少し始める。そして、この時の $\mathrm{P}_{0}$ と $\mathrm{P}_{1}$ との関係は、 $P_{0}=P_{1} \cdot e^{-\mu a_{B}}$ 、即ち、緊張端側を定着端、定着端 側を緊張端とするような関係を保持しながら、両端の張力が減少し ていく。

図 4 にテンドン張力を $T$ で表し、定着時 $\left(T_{A}, T_{B}\right)$, 除荷時（ $T$ ${ }_{A}^{\prime}, T_{C}, T_{B}$ 及び $\left.T_{A}^{\prime \prime}, T_{B}\right)$, 及び再緊張時 $\left(T_{A}^{\prime \prime \prime}, T_{C}^{\prime}, T_{B}\right)$ の張力分布の模式図を示す。模式図を用いて考察すると次のように 言える。A端から除荷寸ることは、A端からテンドンの伸びを戻す ことになるため、その移動量に対态して逆フリクションが作用する ことになる。この逆フリクションの作用で、 $\mathrm{T}_{\mathrm{A}}{ }^{\prime}, \mathrm{T}_{\mathrm{C}}$ 間の張力は、 C側から㗨張した時の緊力分布になると言える。

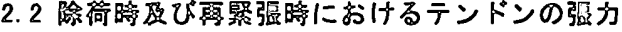

W. Zerna ${ }^{10)}$ は、逆フリクションの作用を利用してテンドンに一定 張力を与える方法を提唱している。W. Zerna の考え方を基に、除荷

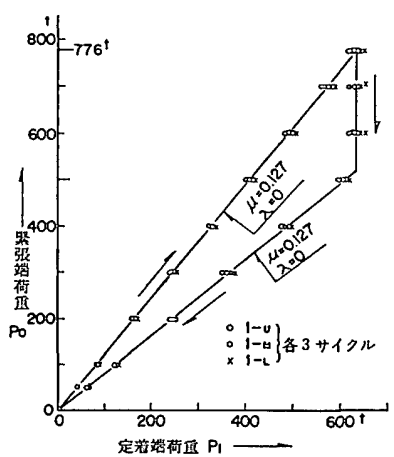

図 3 テンドンの $\mathrm{P}_{0} / \mathrm{P}_{1}$ 関保 $^{9}{ }^{9}$

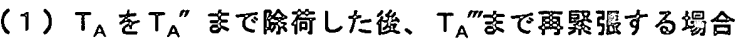

W. Zerna の摩摖損失除去法から推察できるように、再緊張の場合 においても $\quad \mathrm{T}_{\mathrm{A}}^{\prime \prime}<\mathrm{T}_{\mathrm{A}}^{\prime \prime \prime}<\mathrm{T}_{\mathrm{A}}$ の条件であれば $\mathrm{T}_{\mathrm{A}}^{\prime \prime} ， \mathrm{~T}_{\mathrm{B}}$ 間に張力の変化しない $\mathrm{T}_{\mathrm{C}}^{\prime}$ が見れ、そし て、再緊張により $T_{A}^{\prime \prime \prime} ， T_{C}^{\prime}$ 間には図に示すような摩擦力が作用し、 その線上の張力 $T_{i}$ は、図 4 に示寸式で与えられる。

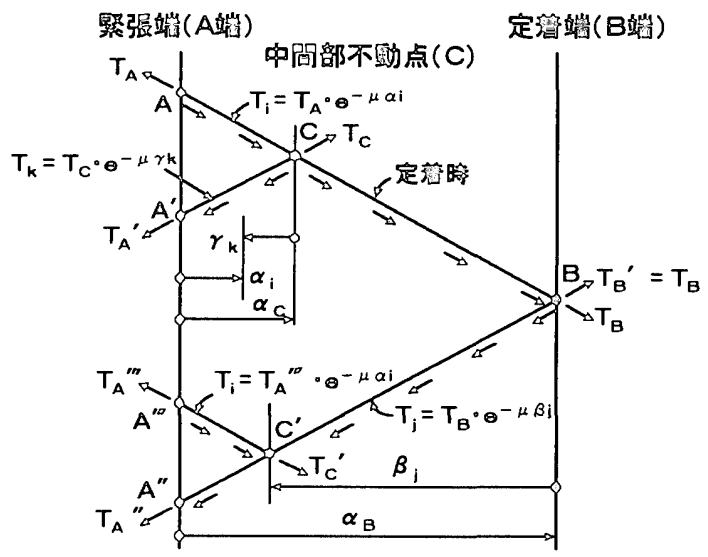

図 4 摩擦力分布とテンドン張力（片引き緊張）

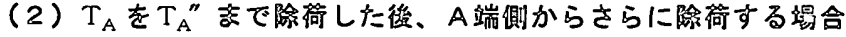

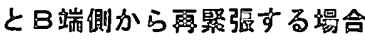

$\mathrm{T}_{\mathrm{A}}$ を $\mathrm{T}_{\mathrm{A}}$ ”まで除荷した後、さらにA端側から除荷しても、その 時のテンドン張力は、 $\mathrm{B}$ 端側から緊張する時の張力分布性状に支配 される。B端側から再緊張する場合も同じである。

図 5 に示される $A$ 端と $B$ 端に扔ける除荷荷重 $\Delta T_{A}{ }^{*}, \Delta T_{B}{ }^{*}$ 及び 增分荷重 $\Delta T_{A}{ }^{+}, \Delta T_{B}{ }^{+}$は、次のように与えられる。

$$
\begin{aligned}
& \left.\begin{array}{l}
\Delta T_{A}^{0}=T_{A}{ }^{\prime \prime}-T_{A}^{\circ}=\left(T_{B}-T_{B}{ }^{\circ}\right) e^{-\mu \beta_{A}} \\
\Delta T_{B}^{\circ}=T_{B}-T_{B}^{\circ}
\end{array}\right\} \\
& \left.\begin{array}{l}
\Delta T_{A}^{+}=T_{A}^{+}-T_{A}{ }^{\prime \prime}=\left(T_{B}^{+}-T_{B}\right) e^{-\mu \beta_{A}} \\
\Delta T_{B}^{+}=T_{B}^{+}-T_{B}
\end{array}\right\} \\
& \therefore \Delta T_{A}^{+}=\Delta T_{B}^{+} \cdot e^{-\mu \beta_{A}} \\
& =\Delta T_{B}^{+} \cdot e^{-\mu \alpha_{B}}
\end{aligned}
$$

ここで、 $\mathrm{e}^{-\mu \alpha \mathrm{B}}$ は、1.0よりも小さいため、 $\mathrm{T}_{\mathrm{A}}$ が $\mathrm{T}_{\mathrm{A}}{ }^{\prime \prime}$ に到達した 後、 $\mathrm{A}$ 端側（低張力側）加ら除荷寸る場合も、B 端側（高張力側） 


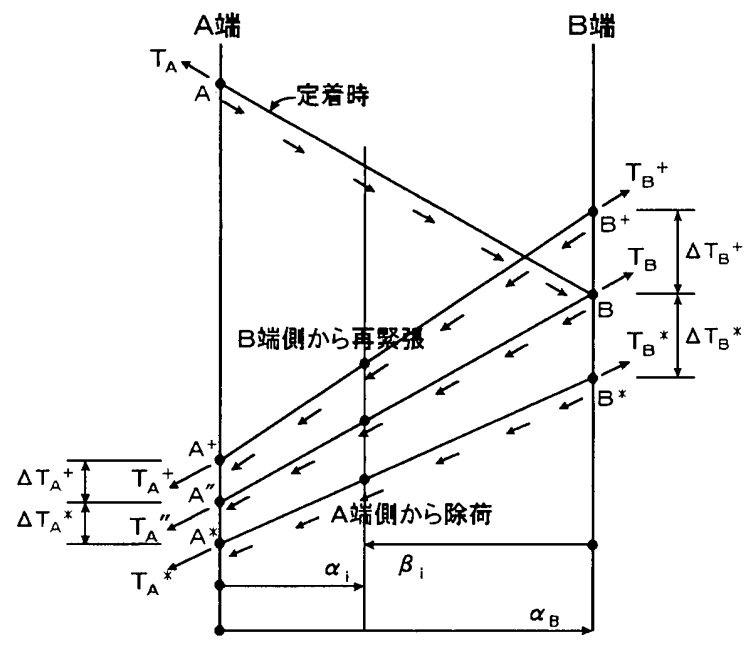

図 $5 \mathrm{~T}_{\mathrm{A}}^{\prime \prime}$ 到達後における $\mathrm{A}$ 端側からの除荷と $\mathrm{B}$ 端側 からの緊張時の摩擦力分布とテンドン張力

から緊張する場合も、A 端側の張力変動量 $\Delta \mathrm{T}_{\mathrm{A}}{ }^{*}, \Delta . \mathrm{T}_{\mathrm{A}}{ }^{+}$に比較し て、B 端側の張力変動量 $\Delta T_{B}{ }^{*}, \Delta T_{B}{ }^{+}$が大きくなる。

\section{3 既往の摩擦力分布に関する考察}

(1) 微少ひずみ変動領域での摩擦力分布とテンドン張カの関係

図3に示した牧野の実験結果 ${ }^{9)}$ では、定着端荷重 $\left(P_{1}\right)$ として プロットされているデータに幅があり、 $\mathrm{P}_{1}$ が一定で $\mathrm{P}_{0}$ が減少した 後、 $P_{1}$ の減少が開始する近傍のデータが確認されていない。従っ て、図 6 の破線で示寸とおり摩擦力が緩和され定着端荷重が徐々に 低下寸る領域が存在寸るものと考えられる。

言い換えると図 7 に示寸形で表現できる。従来の考え方は、除荷 時の張力はC点で不動点となり、摩擦力もその位置で方向が逆転し て不連続的に釣り合う形となる。一方、図 6 の微少ひずみ変動領域 において摩擦力が緩和される領域が存在すると考えると、図 7 の破 線で張力分布が表わされることになり、摩擦力（斜線部）も連続的 に変動すると言える。又、摩擦力の緩和は、後述の図 14，15に於て 温度と張力又はひずみに関する勾配が非線形性を示していることか らも明らかである。

このように微少ひずみ変動領域において、摩擦力が徐々に緩和さ れ、その結果テンドン張力が減少する現象を、摩擦係数の低下に起 因寸るものと見なし、低下した摩擦係数を見掛けの摩擦倸数 $\left(\mu^{*}\right)$ と呼ぶこととする。

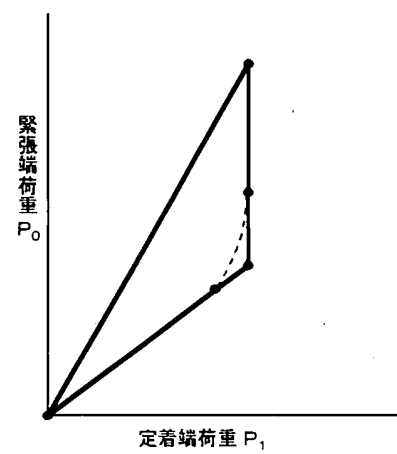

図 6 テンドンの $P_{0}-P_{1}$ 関倸

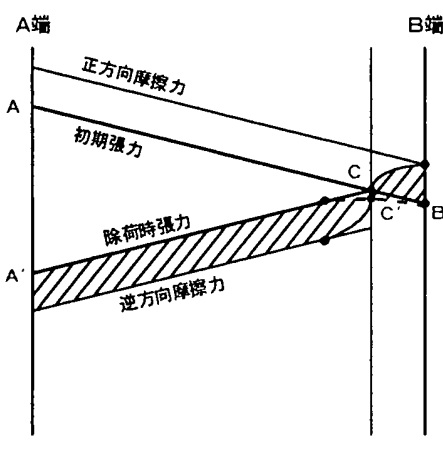

微少ひずみ変動領域での 張力（破線）と摩擦力分布 (斜線部)

\section{3. 熱を受けるテンドンの張カ再配分}

既往の文献によるテンドン張力と摩擦力の関倸に於いてはテン ドンが片側から徐々に移動する場合を対象としたものであり、加熱 実験結果 ${ }^{4)}$ の張力分布とは明らかに異なった性状となる。従って、 熟を受けるテンドンのように全体的にテンドンが移動するような現 象については既往の考え方では説明できない。そこで、熱を受ける テンドンの微少ひずみ変動領域での摩擦理論による張力変動評価式 を本章で提案する。

\section{1 加熱時及び除熱後におけるテンドンの張力再配分}

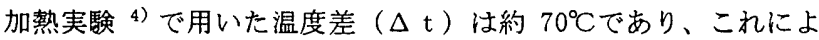
るひずみは約 $700 \times 10^{-6}$ である。これは初期㗨張時ひずみ、約 7000 $\times 10^{-6}$ の $10 \%$ 程度に相当し、温度によるひずみは初期ひずみに対し て微少であると云える。テンドンを曲率半径 $\mathrm{a}(\mathrm{cm})$ のシリンダー に巻き付け、片引きして緊張定着した後、微少ひずみ変動領域にお いて一様な增分温度をテンドンに与えた時の、摩擦力分布と張力と の関係の模式図を、図 8 に示す。

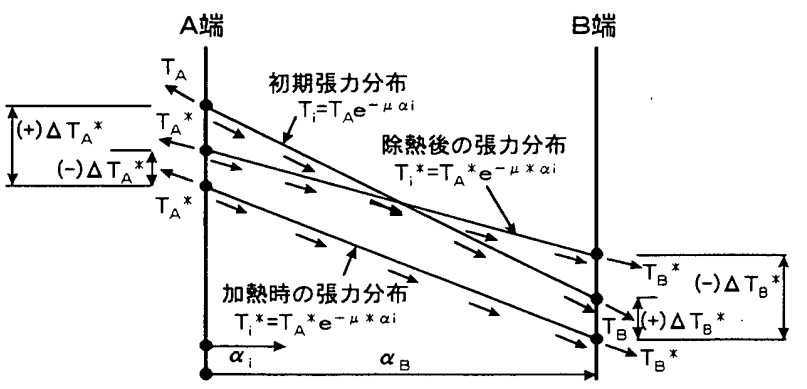

図 8 加熱時及び除熱後の摩擦力分布とテンドン張力

テンドンに一様な增分温度を与えた場合、高張力側の張力减少量 $\Delta T_{A}{ }^{*}$ が低張力側の減少量 $\Delta T_{B}{ }^{*}$ に比較して大きくなることが、前 述の加熱試験 4) で確かめられている。

また、逆に除熱後の場合は、高張力側の張力增大量 $\Delta \mathrm{T}_{\mathrm{A}}{ }^{*}$ が低張 力側の增大量 $\Delta \mathrm{T}_{\mathrm{B}}{ }^{*}$ に比較して小さくなることも確かめられている。 加熱時におけるテンドンの張力再配分性状については、図 5 の低 張力側 (A 端) からの除荷時の張力再配分性状に類似したものであ ると言えるが、除熱後の性状は、図 5 の低張力側からの緊張時の性 状と相違するし、また、高張力側（B 端）からの緊張時の性状とも 相違する。

この理由は、次のことによると推察される。

加熱時及び除熱後では、A，B両端が固定された状態で、テンド ンの熱伸びあるいは熱収縮による張力再配分となるのに対し、除荷 時と緊張時では、一端を固定した状態で、他端からテンドンの伸び を戻すあるいは引き出すことによる張力再配分となることである。 そして、これらの加熱条件、加力条件の差が、テンドンの移動性状 に反映されたと考えられる。

例えば、除荷時について考察する。高張力側から除荷する場合は、 摩擦力を緩和する方向（作用する方向）にテンドンの伸びを戻すた め、摩擦力が解除される領域が当然現れるが、テンドンの移動量が 限界点を超えると逆フリクションが作用し、その先の領域では、テ ンドンの移動は生じない。また、低張力側から除荷する場合は、摩 擦力の作用方向とは逆方向にテンドンの伸びを戻すため、摩擦力が 
増大寸ればテンドンの移動を拘束すると言ってもよいが、実際には 摩擦力そのものが限界状態にあるため、テンドンの移動を拘束でき ない。このため、テンドンの移動が端部から順次進行し、最終的に は、高張力側から緊張した時と同じ張力分布に収斂する。これに対 し、加㛙時では、㛙伸びによるテンドンの移動が、高張力側からの 除荷と同様、摩擦力を緩和する方向に生ずると考えられる。しかし、 剠伸びそのものは、A，B 2 点間の任意の位置に生ずるため、高張 力側からの除荷時のように、逆フリクションが作用する領域が現れ ず、低張力側から除荷した時の張力分布に穎似するものとなったと 考えられる。

除熱後でも、基本的には、加熱時と同じことが言える。熱収縮に よるテンドンの移動は、摩擦力が解除される方向（摩擦力の作用方 向）に現れると考えられ、低張力側から緊張する時の移動性状に近 いと言える。しかし、低張力側から緊張する場合は、逆フリクショ ンが作用する領域が現れるが、除熟後では、このような領域は現れ ず、高張力側から緊張した時の張力分布に穎似するものとなったと 考えられる。以上のことを勘案すると、加熱時及び除㛙後のテンド ンの移動に伴い、摩擦力は減少すると言える。

加熱前の $\mathrm{i}$ 点のテンドン張力を $\mathrm{T}_{\mathrm{i}}$, 摩擦係数を $\mu$, 又、加熱時 あるいは除熟後の $\mathrm{i}$ 点の張力を $\mathrm{T}_{\mathrm{i}}{ }^{*}$ ，見掛けの摩擦倸数を $\mu$ *とす ると、就を受けたテンドンの $\mathrm{B}$ 点及び $\mathrm{i}$ 点の張力, $\mathrm{T}_{\mathrm{B}}{ }^{*}$ 及び $\mathrm{T}_{\mathrm{i}}{ }^{*}$ は (4) 式で表わされる。

$$
\begin{aligned}
& T_{B}^{0}=T_{A}{ }^{\circ} e^{-\mu^{\circ} \alpha_{B}} \\
& T_{i}^{\circ}=T_{A}^{*} e^{-\mu^{\circ} a_{i}}
\end{aligned}
$$

また、テンドンの増分温度 (正符号 : 增分温度, 負符号 : 減少温 度）を $\Delta \mathrm{t}$ ，線膨張係数を $\alpha_{\mathrm{S}}$ ，曲率半径を $\mathrm{a}$ とすると、加熟時（あ るいは除熟後，以下略）のi点のテンドンひずみ $\varepsilon_{\mathrm{i}}{ }^{*}$ は、

$$
\begin{aligned}
\varepsilon_{i}^{*}= & \varepsilon_{\sigma i}{ }^{\circ}+\alpha_{S} \cdot \Delta t \\
; & \varepsilon_{\sigma i}{ }^{*} \text { は、テンドンの応カひずみ }\left(T_{A}{ }^{\circ} / E_{S} A_{S}\right) \\
& \mathrm{E}_{\mathrm{S}} \text { は、テンドンの見措けのヤング係数 } \\
& \mathrm{A}_{\mathrm{S}} \text { は、テンドンの断面䅡 }
\end{aligned}
$$

で与えられる。

加熱前及び加熱時の $\mathrm{A} \sim \mathrm{i}$ 点間におけるテンドンの伸びを $\Delta \ell_{\mathrm{i}}$, $\Delta \ell_{\mathrm{i}}{ }^{*}$ とすると、

$$
\left.\begin{array}{rl}
\Delta \ell_{i} & =\int_{0}^{\alpha_{i}} \varepsilon_{i} a d \alpha_{i} \\
& =\left(a T_{A} / \mu E_{S} A_{S}\right)\left[1-e^{-\mu \alpha_{i}}\right] \\
\Delta \ell i^{\circ} & =\int_{0}^{a_{i}} \varepsilon_{i}^{\circ} a d \alpha_{i} \\
& =\left(a T_{A}^{\circ} / \mu^{\circ} E_{S} A_{S}\right)\left[1-e^{-\mu^{\circ} \alpha_{i}}\right]+\alpha_{S} \Delta t \cdot a \alpha_{i}
\end{array}\right\}
$$

となる。

従って、 $\mathrm{A}, \mathrm{B} 2$ 点間のテンドンの伸びを $\Delta \ell_{\mathrm{AB}}, \Delta \ell_{\mathrm{AB}}{ }^{*}$ とす ると、

$$
\left.\begin{array}{l}
\Delta \ell_{A B}=\left(a T_{A} / \mu E_{S} A_{S}\right)\left[1-e^{-\mu a_{B}}\right] \\
\Delta \ell_{A B}{ }^{\circ}=\left(a T_{A}^{\circ} / \mu^{\circ} E_{S} A_{S}\right)\left[1-e^{-\mu^{\circ} \alpha_{B}}\right]+\alpha_{S} \Delta t \cdot a \alpha_{B}
\end{array}\right\}
$$

で与えられる。

テンドンは、緊張・定着された後、A，B２点が固定された状

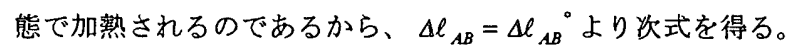

$T_{A}{ }^{\circ}=\left\{(\mu / \mu) T_{A}\left[1-e^{-\mu \alpha_{B}}\right]-\alpha_{S} \Delta t \cdot \alpha_{B} \cdot \mu^{\circ} E_{S} A_{S}\right\} /\left[1-e^{-\mu^{\circ} \alpha_{B}}\right]$

また、加熟による i 点のテンドンの移動量を $\Delta \mathrm{S}_{\mathrm{i}}{ }^{*}$ とすると、 $\Delta S_{i}^{\circ}=\Delta \ell_{i}-\Delta \ell_{i}^{\circ}$

$$
=a\left\{\left(T_{A} / \mu E_{S} A_{S}\right)\left[1-e^{-\mu \alpha_{i}}\right]-\left(T_{A}^{\circ} / \mu^{\circ} E_{S} A_{S}\right)\left[1-e^{-\mu^{\circ} \alpha_{i}}\right]-\alpha_{S} \Delta t \cdot \alpha_{i}\right\}
$$

を得る。

$\mu^{*}$ が一義的に決定されるとすると、（8）式より、温度增分 $\Delta \mathrm{t}$ に対応する $\mathrm{T}_{\mathrm{A}}{ }^{*}$ が求められる。また、（9）式より、 $\mathrm{A}, \mathrm{B} 2$ 点間 の任意の位置におけるテンドンの移動量 $\Delta \mathrm{S}_{i}{ }^{*}$ も求められる。そし て、 $\Delta S_{i}^{\circ}>0$ の領域では、 $\mathrm{A}$ 点に向う移動、 $\Delta S_{i}^{\circ}<0$ の領域では、B 点に向う移動となる。

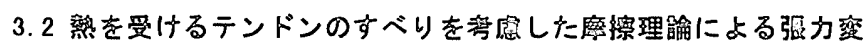

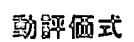

3.1 節で誘導したテンドンのすべりを考慮した摩擦理論による張 力変動式をさらに展開し、加熱試験結果 ${ }^{4)}$ の評価にも使用できる汎 用性のある式を求める。

対象とするテンドンの初期張力分布を、図 9 に示すように、セッ トロス(定着時の鋼線の滑動等によって生じる張力減少)の影響があ る場合を考慮し、ピーク值となる位置をC点とする。さらに、A， $\mathrm{B}$ 端でテンドンを固定とせず、それらの外側に、長さ $\ell_{1}, \ell_{2}$ の テンドン余長があり、そして、それらの端部 $\mathrm{E}, \mathrm{F}$ 点でテンドンが 固定される場合を考える。

また、テンドン余長部分には、摩擦力は作用しないものとし、加 熱前のテンドンの初期張力分布は、2 章の既往の評価式で与えられ るものとする。

ここで、 $\alpha_{\mathrm{B}} ， \alpha_{\mathrm{C}}$ は、初期条件で与えられる既知数である。 $\alpha_{\mathrm{D}}$ は、 テンドン張力の釣合条件と变位連続条件で決定される未知数であり、 加熱による張力再配分後において摩擦力が釣り合い、ピーク張力と なる位置とする。

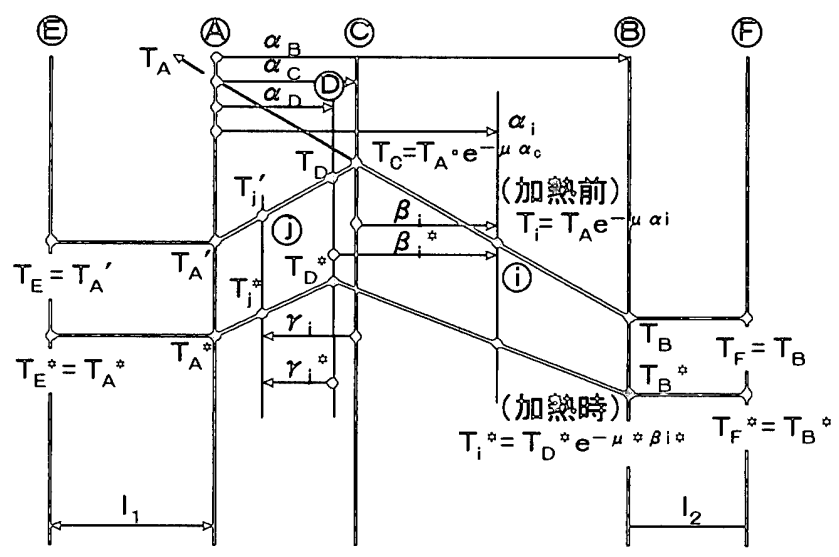

図 9 熟を受けるテンドンの張力再配分模式図 
そして、加熱前におけるテンドン張力を $\mathrm{T}_{\mathrm{i}}$, 加熱時の張力再配 分後のテンドン張力を $\mathrm{T}_{\mathrm{i}}{ }^{*}$ として表示すると、各部張力は、次のよ うに与えられる。

$$
\begin{aligned}
& T_{B}=T_{A} \cdot e^{-\mu a_{B}}=T_{P} \\
& T_{C}=T_{A} \cdot e^{-\mu a_{C}} \\
& T_{A}^{\prime}=T_{C} \cdot e^{-\mu_{Y A}}=T_{A} \cdot e^{-2 \mu \alpha_{C}}=T_{B} \\
& T_{B}^{*}=T_{D}{ }^{*} e^{-\mu^{*} \beta_{B}^{*}}=T_{D} e^{-\mu^{*}\left(a_{B}-\alpha_{D}\right)}=T_{F}^{*} \\
& T_{A}^{*}=T_{D} e^{-\mu^{*} \gamma_{A}^{*}}=T_{D} e^{-\mu^{*} \alpha_{D}}=T_{B}{ }^{*}
\end{aligned}
$$

さらに、 i , j 点におけるテンドンのひずみは、 (加熱前)

$$
\begin{gathered}
\varepsilon_{i}=\varepsilon_{\sigma i}=\left(T_{i} / E_{S} A_{S}\right) \\
\varepsilon_{j}=\varepsilon_{\sigma j}=\left(T / E_{S} A_{S}\right)
\end{gathered}
$$

(加熱時)

$$
\begin{aligned}
& \varepsilon_{i}^{*}=\varepsilon_{\sigma i}{ }^{*}+\alpha_{S} \Delta t \\
& \varepsilon_{j}^{*}=\varepsilon_{o j}+\alpha_{S} \Delta t
\end{aligned}
$$

と与えられる。

以上の応力〜ひずみ関係式を用い、未知数 $\alpha_{\mathrm{D}}$ と $\mathrm{T}_{\mathrm{D}}{ }^{*}$ を求めれば よい。

高張力側から除荷する場合は、テンドンの移動量に対応した逆フ リクションの作用により、D点から先の領域全てにおいて移動が生 じないが、加熱時の場合は、 $\mathrm{D}$ 点を境として、A 端側と B 端側の伸 びの変動量が等価になることにより、移動が生じないと言える。

テンドンのもとの長さを $\ell_{\mathrm{ED}} ， \ell_{\mathrm{DF}}$ とし、加熱前の応力による 伸びを $\Delta \ell_{\mathrm{ED}}, \Delta \ell_{\mathrm{DF}}$, 加熱時の応力と熱ひずみによる伸びを $\Delta$ $\ell_{\mathrm{ED}}^{*}, \Delta \ell_{\mathrm{DF}}^{*}$ とすると、

$$
\begin{aligned}
\ell_{B D}{ }^{\circ} & =\ell_{B D}+\Delta \ell_{B D} . \\
& =\ell_{B D}+\Delta \ell_{B D}=\text { const. } \\
\ell_{D^{P}} & =\ell_{D P}+\Delta \ell_{D P} . \\
& =\ell_{D P}+\Delta \ell_{D F}=\text { const. }
\end{aligned}
$$

とおくことができる。

即ち、

$$
\left.\begin{array}{l}
\Delta \ell_{B D}=\Delta_{B D} \cdot \\
\Delta \ell_{D F}=\Delta_{D F}
\end{array}\right\}
$$

と言う条件式が得られる。

(1) $0 \leqq \alpha_{D} \leqq \alpha_{C}$ の場合

加熱前のテンドンの伸び $\Delta \ell_{\mathrm{ED}}, \Delta \ell_{\mathrm{DF}}$ は、 (16)，(17）式で 表される。

$$
\begin{aligned}
& \Delta \ell_{B D}=\int_{\gamma_{D}}^{\gamma_{A}} \varepsilon_{j} a d \gamma_{j}+\left(T_{A}^{\prime} / E_{S} A_{S}\right) \ell_{1} \\
& \Delta_{D P}=\int_{\gamma_{C}}^{\gamma_{D}} \varepsilon_{j} a d \gamma_{j}+\int_{a_{C}}^{\alpha_{B}} \varepsilon_{i} a d \alpha_{i}+\left(T_{B} / E_{S} A_{S}\right) \ell_{2}
\end{aligned}
$$

同様に、加熱時の伸び $\Delta \ell_{\mathrm{ED}}{ }^{*}, \Delta \ell_{\mathrm{DF}}{ }^{*}$ についても、(18)，(19) 式で表される。

$$
\begin{aligned}
& \Delta \ell_{B D^{*}}=\int_{Y D^{*}}^{\gamma A^{*}} \varepsilon_{j}{ }^{*} a d \gamma_{j}+\left[\left(T_{A}^{*} / E_{S} A_{S}\right)+\alpha_{S} \Delta t\right] \ell_{t} \\
& \Delta_{D P}{ }^{*}=\int_{\beta_{D}}^{\beta_{B}{ }^{*}} \varepsilon_{i}{ }^{*} a d \beta_{i}{ }^{*}+\left[\left(T_{B}^{*} / E_{S} A_{S}\right)+\alpha_{S} \Delta t\right] e_{2}
\end{aligned}
$$

（16）から（19）式を（15）式の条件に当てはめることにより、
各々、 $\mathrm{T}_{\mathrm{D}}{ }^{*}, \mathrm{~T}_{\mathrm{A}}{ }^{*}, \mathrm{~T}_{\mathrm{B}}{ }^{*}$ が得られる。尚、 $\Delta \mathrm{t}$ を正とすれば加熱後, 負とすれば除熱後に对応する式となる。

(2) $\alpha_{C}<\alpha_{D} \leqq \alpha_{B}$ の場合

(16），(17）式の各々、 $\Delta \ell_{\mathrm{ED}}, \Delta \ell_{\mathrm{DF}}$ を下記のように置き換 える。

$$
\begin{aligned}
& \Delta \ell_{B D}=\int_{\gamma_{C}}^{\gamma_{A}} \varepsilon_{j} a d \gamma_{j}+\int_{\beta_{C}}^{\beta_{D}} \varepsilon_{i} a d \beta_{i}+\left(T_{A}^{\prime} / E_{S} A_{S}\right) \ell_{1} \\
& \Delta \ell_{D P}=\int_{\beta_{D}}^{\beta_{B}} \varepsilon_{i} a d \beta_{i}+\left(T_{B} / E_{S} A_{S}\right) \ell_{2}
\end{aligned}
$$

$\Delta \ell_{\mathrm{ED}}^{*}, \Delta \ell_{\mathrm{DF}}{ }^{*}$ は、(18)，(19) 式と同様であるので、上記 （1）と同様、（15）式の関係より、各々、 $\mathrm{T}_{\mathrm{D}}{ }^{*}, \mathrm{~T}_{\mathrm{A}}{ }^{*}, \mathrm{~T}_{\mathrm{B}}{ }^{*}$ が得 られる。

\section{3 実験結果との比較検討}

3.2 節で提案したテンドンのすべりを考慮した摩擦理論による張 力変動評価式を既往の加熱試験結果 ${ }^{4)}$ に適用し、比較検討すること により、対応性を確認する。

\section{3.1 実験内容}

図 10 に、テストベッドの概要を示す。テストベッドは RC 製で直 径 $4.0 \mathrm{~m}$, 高さ $4.8 \mathrm{~m}$ の中実円柱及びそれに付属するマッシブな壁か ら成り、 5 ヶ所にテンドン定着部をモデル化し、シリンダー部 4 ケ 所にテンドンひずみ測定用切欠きを設けた。

テンドンは、 $\phi 5 \mathrm{mmPC}$ 銅線と $\phi 12.4 \mathrm{~mm}$ アンボンド $\mathrm{PC}$ 䤡より線を 用い、各々をテストベッド側面に巻き付け、緊張および加熱を行っ た。シースはテンドンの摩擦の状況を実機の条件に近づけるため、 $\mathrm{PC}$ 鋼材にグリースを付着させ、ポリエチレン被覆しているものを用 いた。

実験パラメータは、テンドンをシリンダーに巻き付ける領域の長 さ（角度変化）、直線部分の長さ及びセットロス量の有無であり、 供試体一覧を表 1 に示す。

緊張力の導入は、片引きで行い、セットロスの有無は、ネジ式治 具を用いてセットロス量を調節できるようにした。そして、加熱は、 電熱加熱方式で行い、熙張、定着した状態のテンドンを約 $80^{\circ} \mathrm{Cまで}$ 加熱し、除熱は自然冷却とした。

テンドン張力の測定は、端部はロードセルにより、又、中間部は テンドンに貼付したストレインダージにより行った。

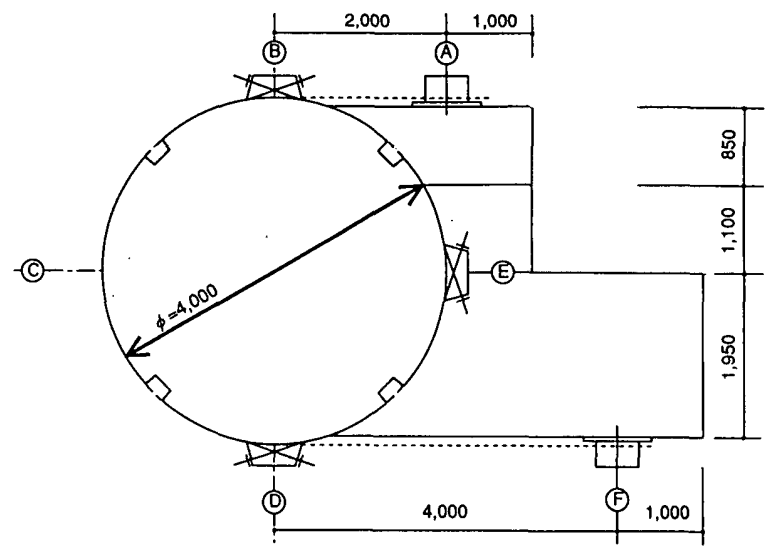

図 10 コンクリートテストベッド 


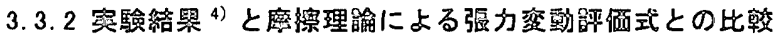

代表例として、申 $5 \mathrm{mmPC}$ 鋼線の H5.0-2.2, H5.0-4.2 及び $\phi$ 12. $4 \mathrm{mmPC}$ 銅より線の HL12.4-4.2 の緊張時、定着時（加熱前）、最 大加熱時及び除就後のひずみ分布を図 11〜図 13 に示す。さらに、 H5. 0-2. 2 供試体の加熟及び除熱後の緊張端と定着端における温度 と端部張力の関倸を図 14 に、又、中間部における温度とひずみの関 係を図 15 に示す。

$$
\text { 表 } 1 \text { 供試体の一覧 }
$$

\begin{tabular}{|c|c|c|c|c|c|}
\hline & 供試体名 & 角度変化 $\left(^{\circ}\right)$ & 定着端 & 堅張端 & セットロス量 \\
\hline \multirow{9}{*}{ 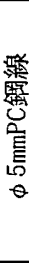 } & H5. $0-1.0$ & 0.0 & A & $\mathrm{B}$ & $\fallingdotseq 0$ \\
\hline & H5. $0-2.1$ & 314.9 & $\mathrm{~B}$ & $\mathrm{~B}$ & $\doteqdot 0$ \\
\hline & H5. $0-2.2$ & 314.9 & $\mathrm{~B}$ & B & $\fallingdotseq 0$ \\
\hline & H5. $0-3.1$ & 157.5 & A & $\mathrm{D}$ & $\doteqdot 0$ \\
\hline & H5. $0-3.2$ & 157.5 & $\mathrm{~A}$ & $\overline{\mathrm{D}}$ & $\doteqdot 0$ \\
\hline & H5. $0-4.1$ & 314.9 & B & B & あり \\
\hline & H5. $0-4.2$ & 314.9 & B & $\mathrm{B}$ & あり \\
\hline & H5. $0-5.1$ & 157.5 & $\bar{A}$ & $\bar{D}$ & あり \\
\hline & H5. 0-5. 2 & 157.5 & $\bar{A}$ & $\bar{D}$ & あり \\
\hline \multirow{9}{*}{ 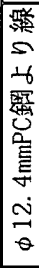 } & HL12.4-1.0 & 0.0 & $\mathrm{~A}$ & B & $\doteqdot 0$ \\
\hline & HL12.4-2.1 & 321.5 & $\bar{B}$ & $B$ & $\fallingdotseq 0$ \\
\hline & HL12.4-2.2 & 321.5 & $\mathrm{~B}$ & $\bar{B}$ & $\doteqdot 0$ \\
\hline & HL12. 4-3.1 & 159.8 & A & D & $\doteqdot 0$ \\
\hline & HL12. 4-3.2 & 159.9 & A & D & $\fallingdotseq 0$ \\
\hline & HL12.4-4.1 & 320.5 & $\bar{B}$ & $\bar{B}$ & あり \\
\hline & HL12.4-4.2 & 321.2 & $\mathrm{~B}$ & $\mathrm{~B}$ & あり \\
\hline & HL12. 4-5. 1 & 160.1 & $\mathrm{~A}$ & $\bar{D}$ & $\Phi り$ \\
\hline & HL12. 4-5. 2 & 159.9 & A & D & あり \\
\hline
\end{tabular}

これらの図に見られるように、張力分布が不均一で、2 点間で固 定されたテンドンが熟を受ける場合、今まで述べてきたとおり、張 力の再配分が現れることが喼められる。その張力再配分の性状は、 加熱時では、高張力側の張力减少が大きく、低張力側が小さくなる のに対し、除熟後では、逆に、高張力側の張力增大が小さく、低張 力側が大きくなる傾向を示す。図 14 に示す緊張端、定着端での温度 と張力との関係、及び図 15 に示すテンドン中間部での温度とひずみ との関倸に於いて、温度と張力又はひずみの勾配から、この性状が 明瞭に現れている。

加熱前の摩擦保数 $\mu$ は、各供試体の毉張時における両端の張力差 から求め、各シリーズ平均值として H5.0 では 0.359 , HL12. 4 では 0.035 の值が得られた。又、同様にして求めた最大加㛙時及び除就後 の見掛けの摩擦係数 $\mu^{*}$ は、それぞれ $\mu^{\circ}=0.88 \mu \quad(\mu$ は緊張時の各 供試体の $\mu), \mu^{\circ}=0.63 \mu$ （ $\mu$ は最大加熱時の各供試体の $\left.\mu\right)$ とな った。最大加熱時の摩擦係数の低下の傾向は、図 11〜図 13 のひず み分布の勾配が㗨張時に比べて楥和されていることにより分かる。

又、除熟後については、同図からは明瞭ではないが、図 16 及び図 17 に示寸 2 点間の張力差をその長さで除した張力勾配が 1.0 以下で あることにより、摩擦倸数が低下していることが分かる。

供試体の代表例について、摩擦理論による張力変動評価式の計算 に用いた条件を表 2 に示し、計算で得られたひずみ分布及び温度と 張力又はひずみの関係を各々、図11〜図13 及び図14〜図15に併記 する。又、全供試体について表 2 の条件と同様にして求めたひずみ の計算値と測定值の比率の平均値（各供試体毎に全測定点で計算値 と測定值の比を求め、相加平均を算出）を表 3 に示す。

図 11〜図 13 に見られるように、加熱，除熱後のひずみ分布に関 する測定值と計算值との対応性はセットロスの有無に拘わらず比較 的良好である。又、図 14〜図 15 に見られるように温度と張力又は ひずみの勾配に関しても対応性が良い。

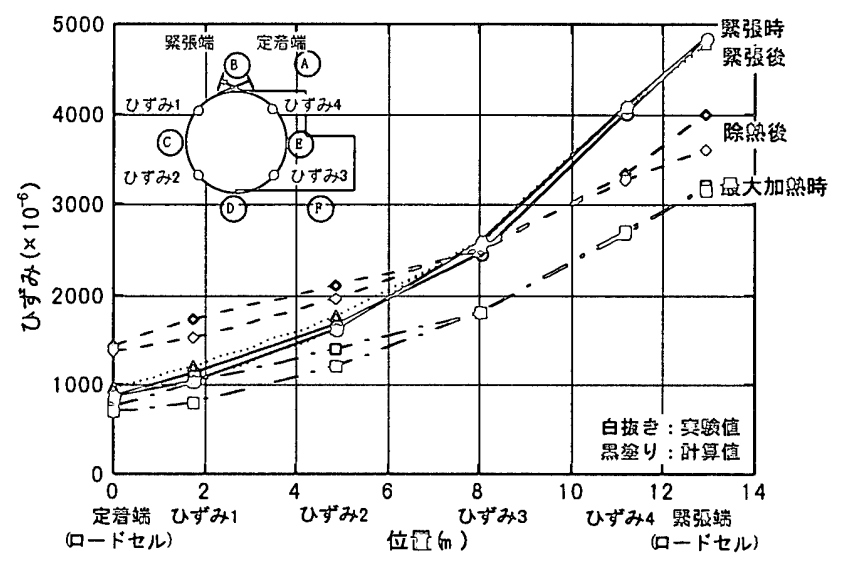

図 11 実験値と計算值のひずみの比較（H5. 0-2.2）

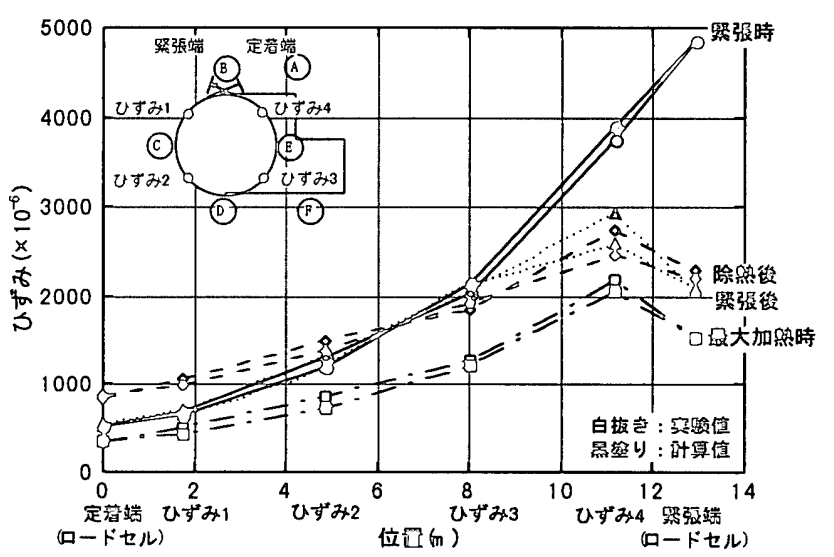

図 12 実験値と計算值のひずみの比較（H5.0-4.2）

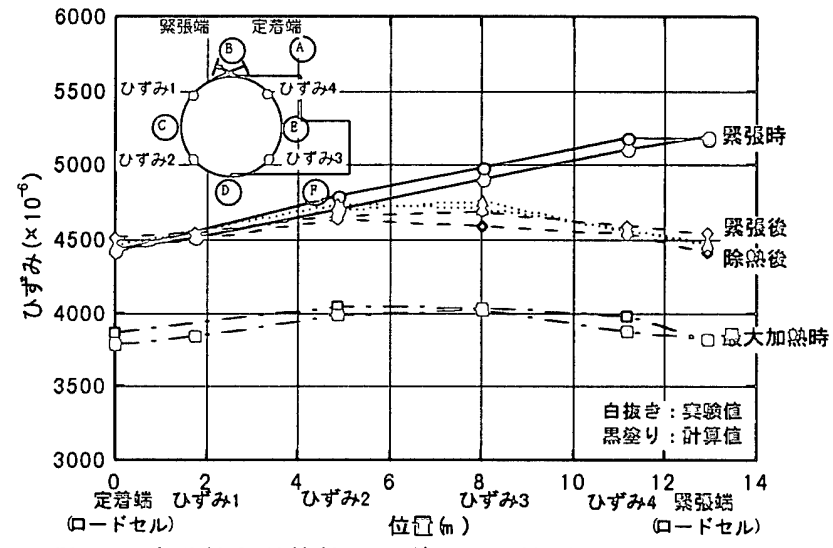

図 13 実験值と計算值のひずみの比較（HL12.4-4.2）

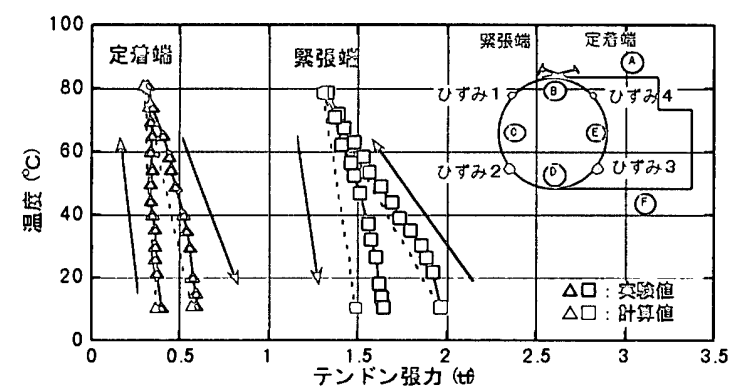

図 14 温度と端部張力の関係（H5. 0-2. 2) 


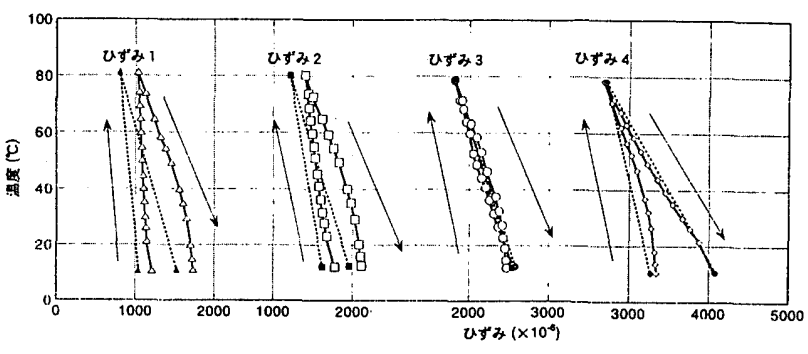

図 15 温度と中間部ひずみの関係（H5. 0-2.2）

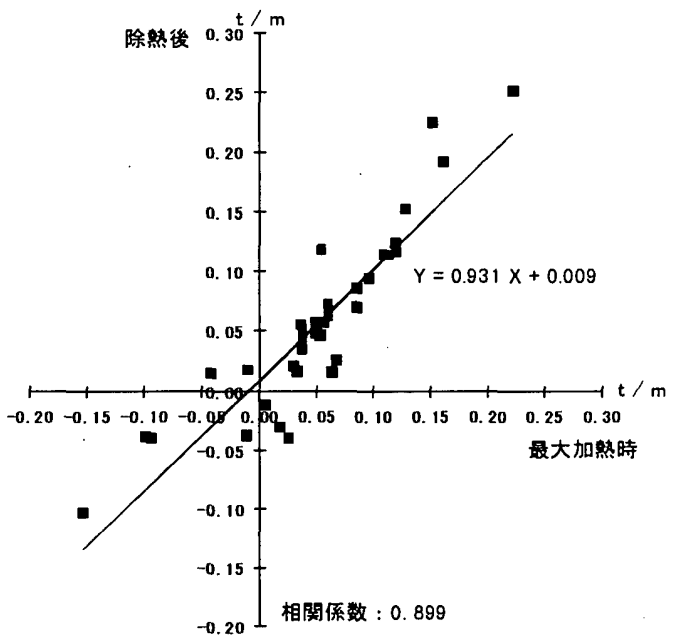

図 16 最大加熱時及び除熱後における張力勾配の散布図（H5.0)

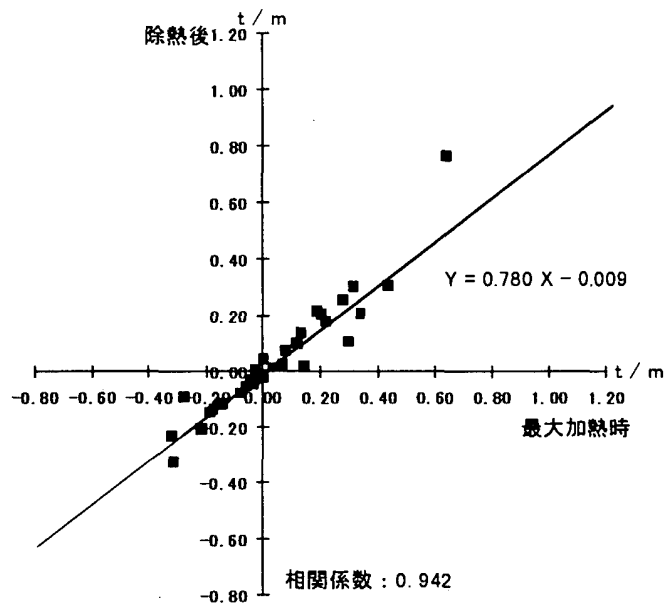

図 17 最大加熱時及び除熱後における張力勾配の散布図（HL12.4）

表 3 各測点での測定値と計算值の比率の平均値

\begin{tabular}{|c|c|c|c|c|c|c|}
\hline \multirow{2}{*}{\multicolumn{2}{|c|}{ 供 試 体 }} & \multicolumn{2}{|c|}{$\begin{array}{c}\text { ひずみの } \\
\text { 測定値/計算值の值 }\end{array}$} & \multirow[t]{2}{*}{ 供 試 体 } & \multicolumn{2}{|c|}{$\begin{array}{c}\text { ひずみの } \\
\text { 測定値/計算値の値 }\end{array}$} \\
\hline & & 最大加熱時 & 除熱後 & & 最大加熱時 & 除熱後 \\
\hline \multirow{11}{*}{ 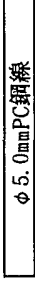 } & H5.0-1.0 & - & - & \begin{tabular}{l|l} 
HL12. 4-1.0 \\
\end{tabular} & - & - \\
\hline & H5. 0-2.1 & 1.00 & 1.02 & 酰 $\mathrm{HL} 12.4-2.1$ & 1.02 & 0.99 \\
\hline & H5. $0-2.2$ & 1.05 & 1.06 & $s$ HL.12. 4-2.2 & 1.03 & 1.00 \\
\hline & H5.0-3.1 & 0.96 & 1.03 & th $\mathrm{HL} 12.4-3.1$ & 1.04 & 1.01 \\
\hline & H5. 0-3.2 & 0.98 & 1.05 & HL12.4-3.2 & 1.02 & 1.01 \\
\hline & H5. $0-4.1$ & 0.93 & 1.00 & HL12. 4-4.1 & 1.01 & 0.98 \\
\hline & H5. 0-4.2 & 1.06 & 1.05 & EL12.4-4.2 & 1.02 & 0.99 \\
\hline & H5. 0-5.1 & 0.92 & 0.98 & HL12. 4-5. 1 & 1.07 & 1.03 \\
\hline & H5.0-5.2 & 0.94 & 1.01 & $\because \mathrm{HL} 12.4-5.2$ & 1.08 & 1.03 \\
\hline & 平均值 & 0.98 & 1.02 & 平均值 & 1.04 & 1.00 \\
\hline & 変動係数 & 0.098 & 0.074 & 変動係数 & 0.050 & 0.036 \\
\hline
\end{tabular}

表 2 実験及び計算条件

\begin{tabular}{|c|c|c|c|c|c|c|c|c|c|}
\hline & 供試 体 & As $\left(\mathrm{cm}^{2}\right)$ & Es $\left(\mathrm{kg} / \mathrm{cm}^{2}\right)$ & $\Delta t\left({ }^{\circ} \mathrm{C}\right)$ & $T A(t)$ & $\alpha \mathrm{B}_{(\mathrm{rad})}$ & $\alpha \mathrm{c}(\mathrm{rad})$ & $\mu(1 / \mathrm{rad})$ & $\mu^{*}(1 / \mathrm{rad})$ \\
\hline \multirow[t]{2}{*}{ H5. $0-2.2$} & 最大加熱時 & 0.1964 & 2. $101 \times 10^{6}$ & 68.4 & 2.00 & 5.4906 & 0.0242 & 0.3123 & 0.2748 \\
\hline & 除熱後 & 0.1964 & 2. $101 \times 10^{6}$ & -68.5 & 1.28 & 5.4906 & 0.0000 & 0.2748 & 0.1731 \\
\hline \multirow[t]{2}{*}{ ค5. $0-4.2$} & 最大加熱時 & 0.1964 & 2. $101 \times 10^{6}$ & 64.5 & 2.00 & 5. 4906 & 1.0497 & 0.4020 & 0.3538 \\
\hline & 除熱後 & 0.1964 & 2. $101 \times 10^{6}$ & -63.9 & 1. 03 & 5. 4906 & 0.6823 & 0.3538 & 0.2229 \\
\hline \multirow[t]{2}{*}{ HL12. 4-4. 2} & 最大加缹時 & 0.9290 & 2. $065 \times 10^{6}$ & 70.2 & 9. 97 & 5. 6057 & 2. 6166 & 0.0282 & 0.0250 \\
\hline & 除熱後 & 0.9290 & 2. $065 \times 10^{6}$ & -68.9 & 8.26 & 5.6057 & 2. 5913 & 0.0250 & 0.0157 \\
\hline
\end{tabular}

ここで, $\alpha \mathrm{s}=1.0 \times 10^{-5}(1 / \mathrm{C}) 、 1_{1}=\left.20 \mathrm{~cm}\right|_{2}=18 \mathrm{~cm} \quad \mathrm{a}=200 \mathrm{~cm}$

又、見掛けの摩擦倸数 $\mu^{*}$ は図 14,15 の実験値からわかるとおり 非線形を示しているが、一定值として扱っても本実験での温度範囲 内では実験值との対応性はそこなわれない。

全供試体について見ると、表 3 に示寸とおり、ひずみの測定值と 計算值の比率の平均値及び全測定点での変動係数は、H5.0 シリーズ が最大加熱時で各々0.98、0.098、除熱後で 1.02、0.074、又、HL12.4 シリーズについては、最大加熱時で各々1.04、0.050、除熱後で 1.00 、 0.036 でありひずみの測定值と計算值はほぼ対応しているものと考 えられる。

\section{4. 結論}

実機 PCCV の残存プレストレスカ評洒法の信頼性をより向上させ るため、テンドン張力の再配分の影響まで考慮した摩擦理論による 張力変動評価式を誘導した。

提案した評価式は、既往の実験結果 ${ }^{4)}$ の張力再配分の傾向をほぼ 表現でき、各位置でのひずみ分布、温度とひずみの関倸の対応性も 良好である。又、各供試体毎のひずみの測定值と計算值の対态性も
良く、変動倸数も0.098〜0.036 と小さい。この結果、本論文で提案 したテンドンのすべりを考慮した摩擦理論による張力変動評価式は 実験結果をほぼ説明できると言える。

今後、実機について評価及び報告の機会が得られた場合には、あ らためて評価結果を報告したい。

\section{謝辞}

本論文の作成に当たり、室蘭工業大学教授 荒井康幸 博士に御 指導を戴きました。又、研究全般に亘って大林組技術研究所の山口 恒雄 部長 から多大なる御支援を戴き、日本原子力発電（株），関 西電力（株），九州電力（株）殿からは貴重なデータを提供して戴 きました。更に、計算等は大林組原子力本部の 野口昌也 氏 に協力 を戴きました。ここで皆様に心より感謝致します。 


\section{参势文献}

1) 川股重也, 北野㴊人 他: コンクリート格納容器の設計と経験, 日本建築学会大会 構造・原子力部門 パネルデスカッション资 料, 1996.9

2) M. Ozaki, T. Abe, Y. Watanabe, A. Kato, T. Yamaguchi and M. Yamamoto : A prediction method for long-term behavior of prestressed concrete containment vessels, Transaction of the 13th SMIRT, vol. H, PP 143-148, 1995

3) S. Tamura, Y. Watanabe, A. Kato, T. Yamaguchi, etc. : A Delayed phenomena Evaluation of prestressed concrete containment vessel at Tsuruga Unit No. 2 power station, transaction of the 11th SMIRT, vol.H, PP 305-310, 1991

4 ) 山本幹夫, 山口恒雄, 加藤朝郎, 桜井和夫, 清原一彦, 山田守 :
熟を受けるテンドンの張力再配分に関する研究, 日本建築学会 学術講演梗概集, B-2 構造 I, PP. 1025 1026, 1995. 8

5 ) 猪股俊司：プレストレストコンクリートの設計および施工，技 法堂, 1959

6 ）六車熙: プレストレストコンクリート，コロナ社, 1989

7 ) 山本幹夫, 山口恒雄 : 熟を受けるテンドンの張力再配分に関す る一考察, 日本建築学会学術講演梗概集, B-2 構造 II, PP. 1079 $\sim 1080,1996.9$

8) 竹本靖他 : PCCV 実大部分モデルによる各種実証試験, プレス トレストコンクリート, VOL. 28, PP. 93〜 95, 1986

9 ) 牧野靖: PCCV 用テンドンの摩擦損失等測定試験, プレストレス トコンクリート, VOL. 23, No. 1, PP. 126〜132, 1981

10) Zerna, W: Beton u. Stahlbetonbau, $47 \mathrm{Jg} . \mathrm{Ht} .11$, 1952. Nov.

（1997年 5 月 10 日原稿受理，1997年 7 月 8 日採用決定） 